\title{
Empirical Investigation Into Customer Adoption Of Islamic Banking Services In Tunisia
}

Hassan Obeid, European Business School Paris, France

Souheila Kaabachi, European Business School Paris, France

\begin{abstract}
This paper seeks to identify the main factors influencing the adoption of Islamic banking by conventional bank customers in Tunisia. Based on a primary data collected by self-administered questionnaires involving a sample of 239 respondents located in Tunis City, the results of this study demonstrate that religious commitment, the amount of information held by consumers about Islamic finance, the relative advantage of Islamic banking and its compatibility with consumer values, lifestyle, and banking habits are predictors of its adoption. However, it is worth noting that social influence does not have any effect on customers' decisions to use this new banking service. The findings also reveal that there is a general lack of information about the Islamic banking among Tunisian consumers. By identifying the drivers of Islamic banking acceptance among potential adopters, this paper aims to help bank managers target their actions and strategies more effectively.
\end{abstract}

Keywords: Islamic Finance in Tunisia; Adoption of Islamic Banking; Islamic Banks; Non-Users of Islamic Banking

\section{INTRODUCTION}

ince its emergence onto the financial scene in the 1970s, Islamic banking has gained prominence, becoming one of the most important players in the banking service industry today. In recent years, it has shown considerable and constant growth with an astonishing annual rate of 15 to 20 percent. The amount of its assets was estimated to be 1.7 trillion dollars in 2013 and is expected to reach 3.4 trillion by 2018 (World Islamic Banking Competitiveness Report, 2013-2014). Due to its significant achievements, Islamic banking has won the admiration of both developed and developing nations. Over the past several years, it has gained popularity in North Africa. Some countries like Tunisia, Libya, and Morocco have shown keen interest in opening up to Islamic banking and have accelerated efforts to introduce Islamic financial institutions.

Despite the arrival of Islamic banking in North Africa in the early 1960s by the establishment of Mit Ghamr Savings Bank in Egypt in 1963 (El-Ghafy \& Khiyar 2012), the sector remains severely underdeveloped in the region, with an overall market share well below 5\% of total banking assets. In 2011, African Development Bank (ADB) pointed out the limited expansion of Islamic banking in North Africa compared to the Gulf region, South East Asia and the United Kingdom. Demirguc-Kunt et al. (2013) report that Islamic banking is still a niche market and its penetration is still low in Algeria, Egypt, Morocco, and Tunisia; only 2 percent of adults in these countries are users of Sharia-compliant banking services. Nevertheless, since the Arab Spring, the demand for Islamic banking services has increased significantly and a great emphasis has been given by North African governments to develop this industry.

This paper is particularly interested in Tunisia, where Islamic finance, despite its emergence in 1983, is still in an embryonic state. The Tunisian banking sector has been dominated by conventional banking for almost a century. Islamic banking is underdeveloped in Tunisia and constitutes in 2012 only 2\% of total financial assets for 1.07 billion USD (Thomson Reuters, 2013). At present, Al-Baraka (an off-shore Islamic bank established in Tunisia on 1983) and Zitouna Bank (the first Islamic local bank launched in 2010) are the only two players allowed to offer Islamic banking financial services to the domestic retail market. After the recent revolution, the government has shown an active interest in Islamic Finance and has stated its intention to assure the establishment and the promotion of the sector in 
the country. According to experts, there is a substantial, untapped market for Islamic banking and finance in Tunisia. The potential demand for Islamic financial assets is estimated to be $40 \%$ of total financial assets, which would represent 28.5 billion USD in 2018 (Thomson Reuters, 2013).

The capacity of the Islamic banking industry to gain substantial market share in a challenging financial environment, particularly in a dual-banking system like Tunisia, will hinge on the ability of Islamic financial institutions to formulate and implement successful marketing strategies. This will require a clear understanding of the behavior, attitudes, and perceptions of their potential consumers (Bobat, 2007). This paper therefore investigates Islamic banking adoption in Tunisia and attempts to identify the significant variables affecting the acceptance of Islamic banking as a new banking service among potential adopters (non-users of Islamic banking products or services, i.e. non-adopters segment). This issue still few explored in the context of Tunisia (Echchabi et al. 2014; Souiden \& Marzouki, 2015; Souiden \& Jabeur, 2015); the present study is intended to fill this gap.

The remainder of this paper is organized into four sections. Section 1 contains a literature review on Islamic banking adoption. Section 2 presents the research methodology and analysis tools adopted in this study. The findings are presented and discussed in section 3 . The concluding section 4 offers practical implications, limitations, and future avenues of research.

\section{LITERATURE REVIEW}

\section{Islamic Bank Patronizing Behavior}

In recent years, Islamic banking adoption has gained special attention in academic studies and numerous researches related to this issue have been conducted across the globe. Most of them reported collectively that factors like religious beliefs, bank reputation and image, good social responsibility practices, accessibility of Islamic banks, trust in Islamic banks and their true compliance with Sharia, quality of services (quality and fast banking; quality and attractiveness of offerings, confidentiality), pricing policies (high profit rates and lower cost financing and service charges) and awareness of Islamic banking plays a significant role in consumer decision to adopt this new banking service (Erol \& El-Bdour,1990; Haron et al.1994 ; Gerrad \&Cunningham ,1997; Metawa \& Almossawi, 1998 ; Dusuki \&Abdullah, 2007; Rammal \& Zurbruegg, 2007; Amin et al. 2011; Thambiah et al. 2011, 2012; Wahyuni, 2012 ; Echchabi \& Aziz, 2012a and b; Faisal et al. 2014; Ismail et al. 2014; Abd. Aziz et al. 2015; Abou-Youssef et al. 2015).

Moreover, numerous studies highlight that variables such as subjective norm, attitude, perceived behavioural control and perceived attributes of Islamic banking including, relative advantage, complexity, compatibility and uncertainty, are also relevant in influencing customers' intention to adopt it (Thambiah et al. 2011, 2012; Echchabi \& Olaniyi, 2012; Echchabi \&Aziz, 2012a; Echchabi \& Abd. Aziz, 2012 b; Ayinde \& Echchabi, 2012; Amin et al. 2013; Echchabi et al. 2014; Ayedh et al. 2014; Abd Aziz et al. 2015, Gumel et al. 2015).

The study of consumer behavior toward Islamic banking in the context of Tunisia has recently received more attention. Various factors like, religiosity, information about Islamic banking, bank's Sharia compliance, competitive rates, bank image, quality of products and their compatibility with the customers' values, lifestyle and financial needs, have been identified as relevant in consumer decision to adopt Islamic banking (Chebab \& Zribi, 2012; Ajili \& Ben Garra, 2013; Thomson Reuters, 2013; Kaabachi \& Obeid, 2014; Slimene et al. 2014; Souiden \& Marzouki, 2015; Souiden \& Jabeur, 2015). Based on a literature review, Figure 1 delineates the research model. 
Figure 1. Research model

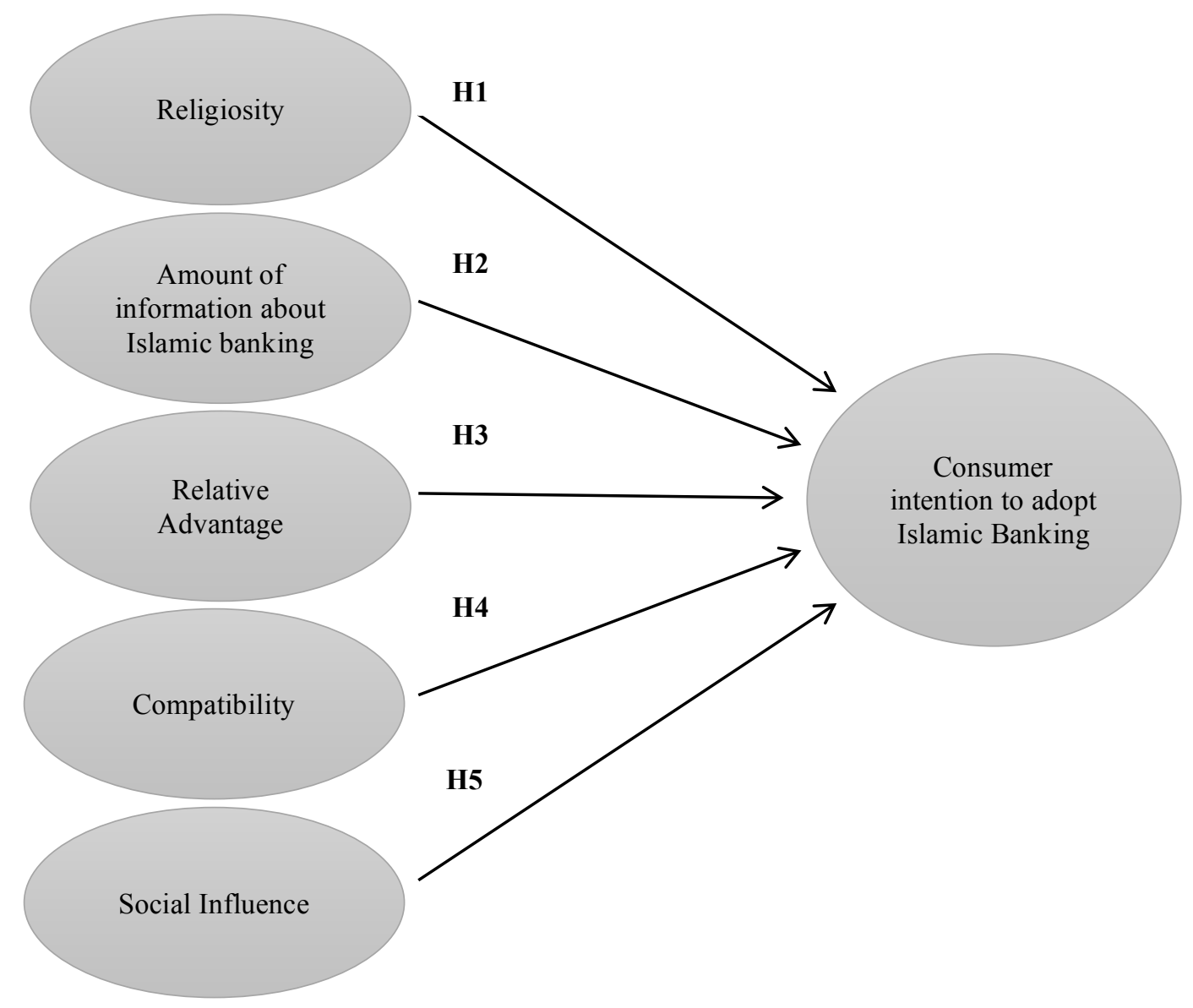

\section{Religiosity}

Islamic banking was introduced to satisfy Muslim customers' request to obtain halal financing or loans that are free from Riba, in accordance with their religious principles. Numerous studies supported the effects of religious affiliation and commitment on consumers' intention to adopt islamic banking (Haron et al. 1994; Metawa \& Almossawi, 1998; Naser et al. 1999; Zainuddin et al. 2004; Dusuki \&Abdullah, 2007; Khan \& Khanna, 2010; Sun et al. 2011; Alam et al. 2012; Echchabi \& Abd Aziz, 2012a; Ismail et al. 2014; Amin et al. 2014; Abou-Youssef et al. 2015).

In the Tunisian context, Thomson Reuters' study (2013), highlight that the bank's adherence to Islamic rules is the most important factors in determining the selection of Islamic banking by Tunisian customers. Similarly, Souiden \& Marzouki (2015) have supported the significant influence of religious beliefs on consumers' attitude towards Islamic banking. In another study, Souiden \&Jabeur (2015) revealed that individuals displaying high Islamic beliefs have a more favorable attitude towards Islamic life insurance and manifest a stronger purchase intention.

Therefore, we posit that:

H1: There is a positive relationship between individuals' religiosity and its intention to adopt Islamic banking.

\section{Amount of Information}

Numerous empirical studies established that the consumer's awareness influence significantly its attitude and intention to use Islamic banking (Gait \& Worthington, 2008; Thambiah et al. 2011; Abdul Hamid et al. 2011; Wahyuni, 2012; Echchabi \& Abdel Aziz, 2012 b, Faisal et al. 2014; Ayinde \& Echchabi, 2012 ; Wahyuni \&Arifin, 2013). It has also been proven that the amount of information is an influential predictor of consumer adoption of Internet banking in an 
Islamic bank (Amin, 2007), mobile phone credit cards (Amin, 2008), Islamic Insurance (Rahim \& Amin, 2011; Ayinde $\&$ Echchabi, 2012) and online waqf services (Amin et al. 2014).

Nevertheless, various studies exploring the status of Islamic banking in Tunisia (BAD, 2011; Bougatef et al. 2012; Ajili \& Ben Gara, 2013; Thomson Reuters, 2013; Kaabachi \& Obeid, 2014; Boulila \& Ben Slama, 2015) pointed out that the Tunisian customers are unfamiliar with concepts and mechanisms of Islamic finance. Therefore, we posit that:

H2: There is a positive relationship between the amount of information that consumers' have about Islamic banking features and benefits and their intention to adopt it.

\section{Relative Advantage}

Relative advantage has been defined as the degree to which an innovation is perceived as better than the idea it supersedes (Rogers, 2003). Several scholars in different areas of adoption and usage studies have concluded that relative advantage is one of the best determinants of the acceptance of an innovation (Tonartzky \& Klein, 1982; Gerrard \& Cunningham, 2003).

Some researchers have shown the main influence of relative advantage on consumers' intention to use Islamic banking (Thambiah et al. 2011; Echchabi \& Abd.Aziz, 2012b; Amin et al. 2013; Abd. Aziz et al. 2015). In these studies, relative advantage of Islamic banking bas been assessed through its functional and ethical benefits, including service quality (knowledge and competence of bank personnel-efficiency in service delivery), pricing policy (costs and benefits of the products and services) and social responsibility practices of Islamic bank (equitable profits, losses and risks sharing in all conduct of banking businesses, contribution to the social welfare of the community and promotion of sustainable development projects). In this paper, we expect that the higher the perceived relative advantage, the stronger the intention to adopt Islamic banking products by potential users. Accordingly, the following hypothesis shall be tested:

H3: There is a positive relationship between perceived relative advantage and consumer intention to adopt Islamic banking.

\section{Perceived Compatibility}

Previous studies in a variety of contexts have indicated that individuals are more likely to accept a new idea or product if that innovation is perceived as compatible with their social system, norms, beliefs, current standards, as well as their lifestyles and values (Tornatzky \& Klein, 1982; Gerrard \& Cunningham, 2003).

Numerous studies supported that consumers tend to adopt Islamic banking if they perceive its congruence with their religious and ethical beliefs, lifestyle, banking habits, and financial needs (Thambiah et al. 2011; Echchabi \& Abd.Aziz 2012b; Ayinde \& Echchabi, 2012; Amin et al. 2013; Abd.Aziz et al. 2015).

Similarly, Echchabi et al. (2014) highlights that compatibility of the Islamic insurance services is an important condition for their acceptance by Tunisian customers. Therefore, we posit that:

H4: There is a positive relationship between perceived compatibility and consumer intention to adopt Islamic banking.

\section{Social Influence}

According to Ajzen (1991), subjective norm refers to an individual's perception of the likelihood that a potential referent group or individuals will approve or disapprove of a given behavior. Several studies have asserted that subjective norm positively affects intention and adoption behaviors in different contexts (Taylor \& Todd, 1995; Venkatesh \& Davis, 2000).

Numerous researchers have found that a consumer decision to adopt Islamic banking was affected by spouses, friends, and relatives (Gerrad \& Cunningham, 1997; Zainuddin et al. 2004; Echchabi \& Abd.Aziz, 2012a; Ayedh et al. 2014; Mahmoud \& Abduh, 2014). It has also been reported that social influence enhances consumer intention to use Islamic 
banking products such as Islamic home financing (Alam et al. 2012; Amin et al. 2013; Ismail et al. 2014; Abd.Aziz et al. 2015), Islamic personal financing (Amin et al. 2011), Islamic credit cards (Amin, 2013), Islamic Insurance (Rahim \& Amin, 2011), Islamic mobile phone banking (Sun et al. 2011), and Internet banking with an Islamic bank (Amin, 2007). Therefore, we posit that:

H5: There is a positive relationship between social influence and consumer intention to adopt Islamic banking.

\section{METHODOLOGY}

\section{Sample}

This study investigates the significant variables affecting the use of Islamic retail banking in Tunisia. Respondents were conventional bank customers who were non-adopters of Islamic banking today. Recent indicators regarding Islamic banking use in Tunisia show that only a small subset of consumers has adopted it, and non-adopters still make up the majority of the target population. Currently, the usage rate of Islamic banking in Tunisia is marginal, about $2 \%$ (Demirguc-Kunt et al. 2013). According to Thomson Reuters (2013), there is substantial interest in Islamic banking from those currently not using it; conventional bank customers seem particularly interested in this banking service.

The current study uses a non-probability convenience sampling technique approach. The adopted convenience sampling method is cost-effective and easy to conduct (Zikmud, 2003). The data was collected from personal interviews using questionnaires. The period of data collection was from April to August 2013. For the data gathering, managers of four branches of conventional banks located in Tunis City were contacted and their collaboration was solicited to distribute the questionnaires to their clients. It is worth mentioning that there are no Islamic banking windows currently operating in Tunisia. A total of 400 questionnaires were distributed and 239 were returned, giving a response rate of $59.75 \%$.

Descriptive analysis has been used to indicate the main characteristics of the sample. Table 1 show that $64 \%$ of the respondents are male and $36 \%$ female. About $74.5 \%$ of the respondents are aged $25-49$ years. The majority of respondents are well-educated, with $25.10 \%$ holding diplomas and about $48.11 \%$ having completed university. Most people interviewed are private-sector employees $(40.58 \%)$.

Table 1. Characteristics of the sample

\begin{tabular}{l|c|c}
\hline \multicolumn{1}{c}{ Variables } & Frequency & Valid Percent \% \\
\hline Gender & & $64 \%$ \\
\hline Male & 153 & $36 \%$ \\
\hline Female & 86 & $8.8 \%$ \\
\hline Age & 23 & $27.2 \%$ \\
\hline $18-24$ & 65 & $47.3 \%$ \\
\hline $25-34$ & 113 & $9.2 \%$ \\
\hline $35-49$ & 22 & $7.5 \%$ \\
\hline $50-65$ & 18 & $0.836 \%$ \\
\hline 65 years or more & & $9.205 \%$ \\
\hline Education Level & 2 & $6.27 \%$ \\
\hline No education & 22 & $9.62 \%$ \\
\hline Primary school only & 15 & $25.10 \%$ \\
\hline High school only & 23 & $48.11 \%$ \\
\hline Secondary school only & 60 & $0.836 \%$ \\
\hline Diploma only & 115 & Valid Percent \% \\
\hline University only & 2 & \\
\hline Postgraduate only & Frequency & $26.35 \%$ \\
\hline Variables & & $40.58 \%$ \\
\hline Professional status & 63 & $23.01 \%$ \\
\hline Public Sector & 97 & $10.04 \%$ \\
\hline Private sector & 55 & 2 \\
\hline Self employed & 24 & \\
\hline Retired & & \\
\hline
\end{tabular}




\section{The Questionnaire Design}

This study used a quantitative method of research in which a structured questionnaire was employed in order to gather relevant data from respondents. The structured questionnaire was designed in consideration of the research conceptual model (see figure I). Measurement tools used in this study were adapted from previous research in the field of adoption studies and usage innovation in addition to a literature review related to Islamic banking. The questionnaire statements were modified according to the results of a pilot test conducted on a representative sample of 30 individuals. The final questionnaire adopted in this study is presented in table 2.

Table 2. Summary of measurement scales

\begin{tabular}{|c|c|c|}
\hline Constructs & Measures & Sources \\
\hline Religiosity & $\begin{array}{l}\text { - I try to follow Islamic injunctions in all matters of my life } \\
\text { - I always try to avoid minor and major sins as told by my religion } \\
\text { - I have firm belief in all basic ideological dimensions of Islam } \\
\text { - I know the basic and necessary knowledge of my religion } \\
\text { - I feel sorrow and dissatisfaction when I do something against my } \\
\text { faith }\end{array}$ & Hanzaee et al.(2012) \\
\hline Amount of Information & $\begin{array}{l}\text { - I have generally received information about Islamic banking } \\
\text { - I have generally received enough information about islamic } \\
\text { banking } \\
\text { - I have received enough information about the features of } \\
\text { islamic banking } \\
\text { - I have received enough information about benefits of using } \\
\text { islamic banking } \\
\text { - I have received information about the instruments used in the } \\
\text { financing products Islamic banks offer (Mudharabah, } \\
\text { Murabaha, Musharaka, Ijaraa) using islamic banking from } \\
\text { media sources }\end{array}$ & Amin et al.(2014) \\
\hline Social Influence & $\begin{array}{l}\text { - People who I listen to could influence me to use Islamic banking } \\
\text { - Most people who are important me support me taking Islamic } \\
\text { banking } \\
\text { - Most of my friends/colleagues have taken Islamic banking agreed } \\
\text { that Islamic finance is better than conventional. }\end{array}$ & Alam et al.(2012) \\
\hline Relative Advantage & $\begin{array}{l}\text { - Financing on the basis of profit -loss-sharing between the } \\
\text { lender and the borrower will be advantageous to both. } \\
\text { - Investments are more secure in Islamic banks } \\
\text { - Islamic banks are more profitable comparing with the interest in } \\
\text { traditional bank (better returns) } \\
\text { - Islamic banks provide lower cost products and services } \\
\text { compared to conventional banking (lower services fees) } \\
\text { - Islamic banks' goal is not only limited to maximization of } \\
\text { shareholders' wealth but also includes enhancement of standard } \\
\text { of living and welfare society } \\
\text { - Islamic banks offer attractive products more than conventional } \\
\text { banks }\end{array}$ & $\begin{array}{c}\text { Bashir (2012) } \\
\text { Alam et al.(2012) } \\
\text { Faisal et al. (2014) }\end{array}$ \\
\hline Compatibility & $\begin{array}{l}\text { - Islamic banking is in line with my values } \\
\text { - Islamic banking fits my needs } \\
\text { - Islamic banking is well suited to my lifestyle } \\
\text { - Using Islamic banking services fits well with the way I like to } \\
\text { manage my finance }\end{array}$ & $\begin{array}{c}\text { Gounaris \& Koritos (2008) } \\
\text { Jansson (2011) }\end{array}$ \\
\hline $\begin{array}{l}\text { Behavioural intention } \\
\text { to use }\end{array}$ & $\begin{array}{l}\text { - I intend to adopt Islamic banking services in the future. } \\
\text { - I predict that I will frequently use Islamic banking services in } \\
\text { the future. } \\
\text { - I will strongly recommend others to use Islamic banking } \\
\text { services. }\end{array}$ & Venkatesh \& Davis (2000) \\
\hline
\end{tabular}


The questionnaire contains three sections. In the first section, the respondents were initially asked to indicate their knowledge about the existence of Islamic banks in Tunisia and their current use of Islamic retail banking deposit and financing schemes. This information was essential to participate in the survey. It ensured the reliability of the answers and guaranteed that the sample consisted only of non-users of Islamic banking. The following section was designed to collect information about the dependent and independent variables proposed in the research model including religiosity, amount of information held about Islamic banking, social influence, relative advantage, compatibility and the consumer intention to adopt Islamic banking. Moreover, five-point Likert scales ranging from 1-Stongly Disagree to 5-Strongly Agree were used to assess responses. A final section on the demographic profile of respondents gathered information on gender, age, education level, and occupation.

\section{DATA ANALYSIS}

Structural equation modeling (SEM) with maximum likelihood estimation using AMOS 18 was adopted to assess both the measurement model and the structural regression model. A two-phase approach was employed to data analysis (Anderson \& Gerbing, 1988).The measurement model was first evaluated to determine the internal consistency and construct validity of the multiple item scales used to operationalize the study variables. Then, the structural model was tested to evaluate the strength and the direction of the relationships between latent constructs.

\section{Measurement Model}

Two-phase analysis procedures were performed to test the measurement model proposed in this study:

First, an exploratory factor analysis using Principal Component Analysis (PCA), followed by a Varimax rotation was employed to identify the factor structure of the concepts. SPSS 18 Software was used to undertake the factor analysis. As suggested by Hair et al. (2009), only those factors with an Eigen value greater than 1 and a factor loading greater than 0.50 were retained for further analysis.

Following these results, a confirmatory factor analysis (CFA) using the Amos 18 package was run, in order to purify the measures employed in this study, examine the dimensionality of the scales, and assess their psychometric properties. The psychometric properties of the measurement model in terms of internal consistency, reliability, convergent validity, and discriminant validity were evaluated. To test the reliability of the constructs, Cronbach's Alpha statistics were calculated. As shown in table IV, all reliability measures were well above the recommended level of 0.07, as an indicator for adequate internal consistency (Nunnally, 1978).

As suggested by Fornell \& Larcker (1981) and Hair et al. (1995), evidence of convergent validity is found when the average variances extracted (AVE) between the constructs and their measures are at least 0.5 and if items loading on their associated factors are well above 0.5. As indicated in Table IV, the items factor loading and the AVE of each construct exceeded the acceptable cut-off of 0.5 ; the convergent validity for all constructs was established. 
Table 3. Psychometric properties of the constructs

\begin{tabular}{|c|c|c|c|c|c|}
\hline Constructs & Items & Loading & Cronbachs alpha (a) & Convergent Validity & AVE \\
\hline Religiosity (REL) & $\begin{array}{l}\text { REL1 } \\
\text { REL2 } \\
\text { REL3 } \\
\text { REL4 } \\
\text { REL5 }\end{array}$ & $\begin{array}{l}0.944 \\
0.864 \\
0.783 \\
0.831 \\
0.910\end{array}$ & 0.90 & 0.67 & 0.753 \\
\hline Amount of information (AI) & $\begin{array}{l}\text { AI1 } \\
\text { AI2 } \\
\text { AI3 } \\
\text { AI4 } \\
\text { AI5 }\end{array}$ & $\begin{array}{l}0.880 \\
0.931 \\
0.925 \\
0.906 \\
0.817 \\
\end{array}$ & 0.906 & 0.84 & 0.79 \\
\hline Relative advantage (RA) & $\begin{array}{l}\text { RA1 } \\
\text { RA2 } \\
\text { RA3 } \\
\text { RA4 } \\
\text { RA5 } \\
\text { RA6 }\end{array}$ & $\begin{array}{l}0.736 \\
0.814 \\
0.799 \\
0.797 \\
0.742 \\
0.609 \\
\end{array}$ & 0.843 & 0.77 & 0.566 \\
\hline Compatibility (COM) & $\begin{array}{l}\text { COM1 } \\
\text { COM2 } \\
\text { COM3 } \\
\text { COM4 }\end{array}$ & $\begin{array}{l}0.901 \\
0.884 \\
0.808 \\
0.855\end{array}$ & 0.880 & 0.67 & 0.747 \\
\hline $\begin{array}{l}\text { Social Influence } \\
\text { (SI) }\end{array}$ & $\begin{array}{l}\text { SN1 } \\
\text { SN2 } \\
\text { SN3 }\end{array}$ & $\begin{array}{l}0.875 \\
0.873 \\
0.803\end{array}$ & 0.801 & 0.894 & 0.721 \\
\hline Behavioural intention to use (BI) & $\begin{array}{l}\text { BI1 } \\
\text { BI2 } \\
\text { BI3 }\end{array}$ & $\begin{array}{l}0.842 \\
0.914 \\
0.928\end{array}$ & 0.875 & 0.85 & 0.801 \\
\hline
\end{tabular}

Table 4. Discriminant validity of constructs

\begin{tabular}{|c|c|c|c|c|c|}
\hline Construct & RA $\quad$ AI & REL & $\mathbf{S N}$ & COM & BI \\
\hline RA & 0.687 & & & & \\
\hline AI & 0.104 & & & & \\
\hline REL & 0.300 & 0.79 & & & \\
\hline SI & 0.049 & 0.105 & 0.84 & & \\
\hline COM & 0.223 & 0.246 & -0.002 & 0.67 & \\
\hline BI & 0.219 & 0.326 & 0.09 & 0.196 & 0.85 \\
\hline
\end{tabular}

Note 2: Diagonal elements (in bold) are the square root of average variance extracted (AVE).

Off-diagonal elements are the correlations among constructs. For discriminant validity, diagonal elements should be larger than the off-diagonal elements.

\section{Results and Hypothesis Testing}

The hypotheses were tested using the structural equations model as shown in Table 5. In this study, the goodness of fit statistics was the main criteria used in testing the hypothesis models. The standardized path coefficients $(\beta)$ and corresponding t-values were examined to test the significance and strength of the relationship between the dependent and independent variables. The model's key statistics are good and acceptable since the CMIN/DDLl=1.196; GFI $=0.913 ; \mathrm{AGFI}=0.878 ; \mathrm{CFI}=0.989 ; \mathrm{NFI}=0.936 ; \mathrm{TLI}=0.985 \mathrm{RMSEA}=0.029(0.013 ; 0.040), \mathrm{SRMR}=0.032$. We can, thus, conclude that the research model is valid and fits the data. 
Table 5. Assessment of the structural model

\begin{tabular}{|c|c|c|c|c|c|c|}
\hline $\mathbf{N}^{\circ}$ & \multicolumn{2}{|c|}{ Hypothesis path } & Parameter Estimate $(\beta)$ & t-Value & p-Value & Results \\
\hline H1 & REL & BI & 0.331 & 5.012 & $0.000 * * *$ & Supported \\
\hline H2 & AI & BI & 0.107 & 2.393 & $0.017 * *$ & Supported \\
\hline H3 & RA & BI & 0.293 & 2.558 & $0.011 * *$ & Supported \\
\hline H4 & COM & BI & 0.322 & 3.438 & $0.000 * * *$ & Supported \\
\hline H5 & SI & BI & -0.125 & -1.893 & 0.058 & Rejected \\
\hline
\end{tabular}

Note 1: ***Significance at $p<0.001, * *$ Significance at $p<0.05$,

Note 2: RA: Relative advantage, COM: Compatibility, PR: Perceived risk, REL: Religiosity, SI: Social influence, BI: Bihavioural intention.

\section{DISCUSSION AND MANAGERIAL IMPLICATIONS}

The study aims to examine the factors affecting the adoption of Islamic banking in Tunisia.

Religiosity emerged as the best predictor of acceptance of this new banking service by Tunisian consumers. This finding is in line with Souiden \& Marzouki (2015) and Souiden \& Jabeur (2015) studies who supported the significant impact of religiosity on Tunisian consumer decisions to adopt Islamic banking as well as Thomson Reuters' report (2013) which indicated that adhering to Islamic rules is a critical concern for Tunisian consumers likely to use Islamic banking products and services. This suggests that Tunisian Islamic banks should promote their services primarily to people or communities that express a high level of religious commitment. Some religious subsets expect that all financial transactions, activities, and investments undertaken by Islamic banks be Sharia-compliant. This can be seen as a form of trust that they have toward these financial institutions. Authenticity is therefore a key element to the growth of Islamic banking in Tunisia. As a result, Islamic financial institutions have to convince potential clients that they provide secure banking products that are fully consistent with Islamic principles.

The amount of information that consumers have about Islamic banking influences their intention to adopt it. This finding is supported by previous studies in this domain (Amin, 2007; Rammal\& Zurbruegg, 2007; Amin, 2008; Rahim \& Amin, 2011; Thambiah et al. 2011; Echchabi \& Abd.Aziz, 2012b; Wayhuni et al. 2012; Wahyuni \& Arifin, 2013 ; Amin et al. 2014). Nevertheless, our result contradicts with the findings of (Abdul Hamid et al. 2011; Echchabi et al. 2014; Abd. Aziz et al. 2015) which showed that awareness of Islamic banking services does not have any influence on the customers' intention to adopt it. The result of the descriptive statistical analysis presented in Table VIII. 1 and Table VIII.2 reveals that $100 \%$ of respondents are aware of the existence of Islamic banking in Tunisia. However, most respondents had not received adequate information about Islamic banking as a whole. They claimed not to have received enough information about the features of Islamic banking (35\%), its benefits (57\%), and financing schemes like Mudharabah, Murabaha, Musharaka, and Ijaraa. The findings are consistent with those of other studies on Islamic finance in the Tunisian context (BAD, 2011; Bougatef et al. 2012; Ajili \& Ben Gara, 2013; Thomson Reuters, 2013; Kaabachi \& Obeid, 2014; Boulila \& Ben Slama, 2015) which reported a lack of awareness and understanding of Islamic banking among Tunisian consumers. In fact, a large proportion of respondents did not have a clear understanding of Islamic financial concepts and of financial structures, and they expressed a need for better education about Islamic banking. The absence of government support and the limited marketing made by Islamic banks established may explain the lack of information about Islamic banking. It is therefore imperative for banks to design informative and effective advertising campaigns about Islamic banking. That will increase the availability of information about the functioning of the Islamic banking system, its features, objectives, and benefits, as comparted to the conventional system. The spiritual, economic, and ethical value provided by Islamic banking has to be particularly noticeable and pointed out to banking customers to enhance their motivation to use it. Improving dissemination of information about Islamic banking is a way to influence consumer perceptions pertaining to this new banking service. This implies that the more information consumers have about Islamic banking, the more such services will be perceived as useful and easy for them to use. 
Table 6. Respondents' awareness level towards Islamic Banking in Tunisia

\begin{tabular}{l|c|c|c|c}
\hline \multirow{2}{*}{ Awareness toward Islamic banking in Tunisia } & \multicolumn{2}{|c|}{ Yes } & \multicolumn{2}{c}{ No } \\
\cline { 2 - 5 } & Frequency & Percent & Frequency & Percent \\
\hline
\end{tabular}

Table 6.1. Amount of information about Islamic banking

\begin{tabular}{|c|c|c|c|c|c|}
\hline Statement & Strongly Disagree & Disgree & Neutral & Agree & Strongly Agree \\
\hline $\begin{array}{l}\text { I have generally received information } \\
\text { about Islamic banking }\end{array}$ & $43.8 \%$ & $35 \%$ & $5.5 \%$ & $9.8 \%$ & $5.9 \%$ \\
\hline $\begin{array}{l}\text { I have generally received enough } \\
\text { information about islamic banking }\end{array}$ & $55.6 \%$ & $33 \%$ & $9.5 \%$ & $1.2 \%$ & $0.7 \%$ \\
\hline $\begin{array}{l}\text { I have received enough information about } \\
\text { the features of islamic banking }\end{array}$ & $35 \%$ & $25.6 \%$ & $16.9 \%$ & $15.2 \%$ & $7.3 \%$ \\
\hline $\begin{array}{l}\text { I have received enough information about } \\
\text { benefits of using islamic banking from } \\
\text { media sources }\end{array}$ & $57 \%$ & $32.7 \%$ & $4.1 \%$ & $2.3 \%$ & $3.9 \%$ \\
\hline $\begin{array}{l}\text { I have received information about the } \\
\text { instruments used in the financing } \\
\text { products Islamic banks offer } \\
\text { (Mudharabah, Murabaha, Musharaka, } \\
\text { Ijaraa) }\end{array}$ & $65.5 \%$ & $31 \%$ & $2.1 \%$ & $1.3 \%$ & $0.1 \%$ \\
\hline
\end{tabular}

Perceived relative advantage emerged as a predictor of consumer acceptance of Islamic banking services. The finding is in line with those of Thambiah et al. (2012), Echchabi \& Abd.Aziz (2012b), Amin et al. (2013), as well as Abd. Aziz et al. (2015). This contradicts with the results of Echchabi et al. (2014) who indicated that relative advantage does not have a significant influence on Tunisian consumer intention to adopt Islamic Insurance. This means that the more Islamic banks are perceived as being financially profitable, secure, fair, and socially responsible, the more opportunity they will have to be accepted by potential adopters. Nevertheless, our research revealed that approximately $57 \%$ of respondents have little awareness about Islamic banking benefits. This is in keeping with Echchabi et al. (2014) findings who highlights that Tunisian customers seem not to acknowledge the relative advantage of either Islamic or conventional insurance and this may be due to the low level of awareness.

Therefore, to help consumers appraise the value and usefulness of Islamic banking, it seems essential for Islamic banks to improve consumer knowledge about their competitive advantage compared to conventional banking services. They should underscore the benefits of using Islamic banking services in their promotional campaigns. In addition to the religious and financial advantages, Tunisian Islamic banks ought to highlight their goal of contributing to the growth of the country's economic and social development. This is particularly important in Tunisia, which has faced economic crises and social tensions after the Arab Spring.

Compatibility is the second most important variable impacting consumer intentions to use Islamic banking services. This finding reflects those of Thambiah et al. (2011); Ayinde \& Echchabi (2012); Echchabi \& Abd.Aziz (2012 b) as well as Abd.Aziz et al. (2015) which indicate that consumers will be more willing to use Islamic banking if it is perceived as congruent with their religious and ethical values, lifestyle, banking habits, and financial needs. Echchabi et al. (2014) reported that compatibility of the Islamic insurance is an important condition for their adoption in Tunisia and that the Tunisian customers' are still attached to their religious and social values. This suggests that bank managers should communicate the idea that Islamic banks (represented by their top personnel and policy makers) share common beliefs with their current and potential clients and promote Islamic norms and ethical values as a way of life. Moreover, it is important to demonstrate the consistency of this new banking system with consumers' current banking habits, needs, and lifestyles. The conventional banking system has been operating for decades and is rooted in the mind of banking consumers in Tunisia, creating well-anchored banking habits and a resistance to change. In order to stimulate consumer demand toward Islamic banking, financial institutions must promote the culture of Islamic banking among Tunisian consumers. Better awareness about Islamic banking and its main benefits can motivate potential adopters to divert their banking habits and reduce their reluctance to change. 
Furthermore, social influence does not have a significant influence on adoption. This is in line with the findings of Echchabi \& Abd.Aziz (2012a), Ayinde \& Echchabi (2012), Wahyuni, (2012). Echchabi et al. (2015) reported that social influence does not have a significant influence on adoption of Islamic Insurance in Tunisia. This contradicts with the results of Zainuddin et al. 2004; Echchabi \& Abd.Aziz, 2012a ; Amin et al. 2013; Ayedh et al. 2014; Mahmoud \& Abduh, 2014; Ismail et al.2014; Abd.Aziz et al. 2015). As a result, it can be concluded that consumer attitudes and behaviors toward the use of Islamic banking do not seem to be affected by the endorsement of family and friends but rather by objective information sourced from exposure to the promotional campaigns conducted by Islamic financial institutions. Islamic banks should therefore adjust their promotional efforts by using mass media outlets, which are primarily knowledge creators (Rogers, 1995).

\section{CONCLUSION}

This research explores the acceptance of Islamic banking in a novel context like Tunisia. From a theoretical standpoint, the findings supports prior studies that highlight the significant effect of religiosity, amount of information, relative advantage, and compatibility on consumers' intentions to use Islamic banking services. The vast majority of work investigating and acknowledging the relevance of those factors on Islamic banking adoption has primarily been conducted in countries where Islamic finance is in its development stage (Thambiah et al. 2011; 2012; Ayinde \& Echchabi, 2012; Amin et al. 2013; Echchabi et al. 2014; Abd Aziz et al. 2015, Gumel et al. 2015). With the exception of Echchabi \& Abd.Aziz (2012a, 2012b) in Morocco and Echchabi et al. (2015) in Tunisia, few studies have explored this issue in the Maghreb and particularly in the Tunisian context where Islamic financing is still in its nascent stage.

A number of major implications for Islamic banks arise from the results of this study. Clearly, consumer education and trust will be key factors in the rapid expansion of Islamic banking in Tunisia. Islamic banks should therefore pay attention to their authenticity in terms of Sharia compliance as well as to their communication policy to attract potential consumers. Bank managers should opt for informative and persuasive advertisements that highlight the "islamacity of product". It's recommended to inform consumers in their promotional campaigns that Islamic institutions are continuously monitored by "the Sharia committee", which ensures that all banking transactions and activities are in line with the rules of Sharia. These arguments could attract a segment of consumers who want to be in harmony with the prescriptions of their religion and hence their trust toward Islamic banks.

Several studies have pointed out that an understanding of Islamic finance is weak in the Arab-Muslim world. According to them, that has been one of the key causes of confusion and misperception about Islamic finance. The implementation of consistent population education programs and awareness campaigns is essential to increase consumer understanding and confidence with respect to Islamic banking. Islamic banks need to intensify their promotional efforts to instill the culture of Islamic banking in the Tunisian people. They should pay special attention to their communication message, by providing detailed, useful, and clear information about how Islamic banking services function and why they would benefit them and for the country's economic and social development.

This study has its limitations, and a discussion thereof will help clearly establish boundaries and identify future avenues for research. Our first limitation relates to the sample. First, the convenience sampling method was adopted in this current study. In this regard, the sample is not representative of the target population and the results should not be generalized to the whole Tunisian population. Second, the sample used in this study was composed only of nonusers of Islamic banking services. Future research should attempt to do comparative analyses between customers and non-customers of Islamic banks, so that more precise results on factors affecting the adoption of Islamic banking services among the two target groups can be identified.

Another limitation relates to the variables employed. The variables used in the current study were not exhaustive, and future studies could further extend the model tested by including a richer set of variables such as attitude, corporate image, consumer awareness, governmental roles, promotional efforts, and service quality as key determinants to provide better understanding of Islamic banking acceptance.

Despite the above-mentioned limitations, the findings of the present study add value by providing insight into the factors leading to Islamic banking acceptance in Tunisia. Overall, it is hoped that the present study's findings will encourage more research in the area of Islamic financing products in the Maghreb, and particularly in Tunisia. 


\section{AUTHOR BIOGRAPHY}

Doctor Hassan Obeid is head of the Finance and Accounting department at European Business School, Paris. His areas of research include company performance, bank efficiency, ICT and privatization. He is a member of the editorial board for academic journals. He has worked for AACSB accredited universities such as United Arab Emirates University and IESEG. E-mail: hassanobeid@ebs-paris.com (corresponding author)

Doctor Souheila Kaabachi is assistant professor of Marketing at European Business School, Paris. His areas of research include Islamic Banking, Experiential Marketing, Relational Marketing and Senior Marketing.

\section{REFERENCES}

Abd. Aziz, H., Echchabi, A., Houssem Eddine, C.O., Ayedh, A.M., Musse, O.S.H. \& Azouzi, D.(2015). Current state and future prospects of Islamic banking in Morocco: An empirical investigation. Journal of Emerging Economies \& Islamic Research, 3 (2), 1-10.

Abdul-Hamid, M., Yaakub, N.I., Mujani, W.K., Sharizam, M. \& Jusoff, K. (2011). Factors adopting Islamic home financing: A case study among consumers of Islamic bank in Malaysia. Middle East Journal of Scientific Research, 7 47-58.

Abou-Youssef, M.M.H., Kortam, W., Abou-Aish, E. \& El-Bassiouny, N.(2015). Effects of religiosity on consumer attitudes toward Islamic banking in Egypt. International Journal of Bank Marketing, 33(6) 786-807.

African development bank (2011). Islamic banking and Finance in North Africa, Past Development and Future Potential. Retrieved from http://www.afdb.org/.../Montage\%20Islamic\%20Banking\%.

Ajili, W. \& Ben Garra, Z. (2013). What for Future For Islamic Finance In Tunisia?. Etudes en Economie Islamique, 7(1) 31-70.

Ajzen, I. (1991). The theory of planned behavior. Organizational Behavior and Human Decision Processes, 50(2) $179-211$.

Alam, S.S., Janor, H., Che Wel, C.A., \& Ahsan, M.N. (2012). Is Religiosity an Important Factor in Influencing the Intention to Undertake Islamic Home Financing in Klang Valley. World Applied Sciences Journal, 19(7) 1030-1041.

Amin, H. (2007). An empirical investigation on consumer acceptance of internet banking in an Islamic Bank. Labuan Bulletin of International Business \& Finance, 5 41-60.

Amin, H. (2008). Factors affecting the intentions of customers in Malaysia to use mobile phone credit cards. Management Research News, 31(7) 493-503.

Amin, H. (2013). Factors influencing Malaysian bank customers to choose Islamic credit cards: Empirical evidence from the TRA model. Journal of Islamic Marketing, 4(3) 245-263.

Amin, H., Abdul-Rahman, A.-R., \& Abdul-Razak, D. (2013). An integrative approach for understanding Islamic home financing adoption in Malaysia, International Journal of Bank Marketing, 31(7) 544-573.

Amin, H., Abdul-Rahman,A.R., Ramayah, T., Supinah.,T., \& Aris., M.M. (2014). Determinants of Online Waqf Acceptance: An Empirical Investigation. The Electronic Journal on Information Systems in Developing Countries, 60(8)1-18.

Amin, H., Rahman, A.R.A., Sondoh, JR.S.L., \& HWA, A.M.C. (2011). Determinants of Customers' Intention to Use Islamic Personal Financing: The case of Malaysian Islamic Banks, Journal of Islamic Accounting and Business Research, 2(1) $22-42$.

Anderson, J.C., \& Gerbing, D.W. (1988). Structural Equation Modeling in Practice: A Review and Recommended Two-Step Approach. Psychological Bulletin, 103(3) 411-423.

Ayedh, A.M., Echchabi, A. \& Alnahari, A.A (2014). Islamic Banking in Yemen in Light of the Arab Uprising: An Empirical Study from Customers' Perspective. Journal of Applied Sciences, 14 (22), 3001-3007.

Ayinde, L., \& Echchabi, A. (2012). Perception and Adoption of Islamic Insurance in Malaysia: An Empirical Study. World Applied Sciences Journal, 20 (3) 407-415.

Bashir, M.S. (2012). Analysis of Customer Satisfaction with the Islamic Banking Sector: Case of Brunei Darussalam. Asian Journal of Business and Management, 2 (10) 38-50.

Bobat, Y. (2007). Islamic Banking: Need Need for Innovation, Paper presented at the Fifth International Islamic Finance Conference, 3-4th September, Kuala Lumpur.

Bougatef, K., Jaouadi, H., \& Kaddour, A. (2012). Understanding the major causes of Islamic Finance Under-development in Tunisia, International Journal of Accounting and Financial Reporting, 2(1) 166-173.

Boulila Taktak, N. \& Ben Slama Zouari, S.(2014). Tunisia Islamic finance: overview and future prospects. Journal of Islamic Accounting and Business Research, 5(1), 2-14.

Chebab, S. \& Zribi, H. (2012). Expected regret and Islamic banking in emerging countries: The case of Tunisia, Journal of Business Studies Quarterly, 3 (4)119-131.

Demirguc-Kunt, A.,Klapper, L., \& Randall, D. (2013). Islamic Finance and Financial Inclusion Measuring Use of and Demand for Formal Financial Services among Muslim Adults. Workings paper No 6642. The World Bank Development Research Group Finance and Private Sector Development Team. Retrieved from: http:// elibrary.worldbank.org/doi/pdf/10.../1813-9450-664.

Dusuki, A., \& Abdullah, N. (2007). Why do Malaysian Customers Patronize Islamic Banks?. International Journal of Bank 
Marketing, 25(3)142-160.

Echchabi, A. Olorogun, L.A., \& Azouzi, D. (2014). Islamic insurance prospects in Tunisia in the wake of the Jasmine revolution: A survey from customers' perspective. Journal of Islamic Accounting and Business Research, 5(1), 15-28.

Echchabi, A., \& Abd. Aziz, H. (2012). Empirical Investigation of Customers' Perception and Adoption towards Islamic Banking Services in Morocco. Middle-East Journal of Scientific Research, 12(6) 849-858.

Echchabi, A., \& Abd. Aziz, H. (2012). Modelling The Patronisation Behaviour Of Islamic Banks' Customers In Morocco. International Journal of Management and Strategy, 3(5) 1-14.

Echchabi, A., \& Olaniyi, O.N. (2012). Using Theory of Reasoned Action to Model the Patronisation Behaviour of Islamic Banks' Customers in Malaysia. Research Journal of Business Management, 6(3) 70-82.

El-Galfy, A., \& Khiyar, K.A., (2012). Islamic Banking And Economic Growth: A Review. Journal of Applied Business Research, 28(5) 943-956.

Erol, C., Kaynak, E., \& El-Bdour, R. (1990). Conventional and Islamic Banks: Patronage Behaviour of Jordanian Customers. International Journal of Bank Marketing, 8(4) 25-35.

Faisal, M., Akhtar, A., \& Rehman A. (2014). Awareness of Islamic Banking in India-an Empirical Study. Retrieved from: http://www.wbiconpro.com/606-Faisal.pdf,1-14.

Fornell, C., \& Larcker, D.F. (1981). Evaluating Structural Equation Models with Unobservable Variables and Measurement Error. Journal of Marketing Research, 18(1) 39-80.

Gait, A.,\&Worthington, A. (2008). An empirical survey of individual customer, business firms and financial institution attitudes towards Islamic methods of finance. International Journal of Social Economics, 35 (11) 783-808.

Gerrad, P., \& Cunningham, J.B. (1997). Islamic Banking: a Study in Singapore. International Journal of Bank Marketing, 15(7) 204-216.

Gerrad, P., \& Cunningham, J.B. (2003). The diffusion of Internet Banking among Singapore. International Journal of Bank Marketing, 21(1)16-28.

Gounaris, S., \& Koritos, C. (2008). Investigating the Drivers of Internet Banking Adoption Decision. International Journal of Bank Marketing, 26(5) 282-304.

Gumel, A.M., Othman, M.A. \& Yusof, R.M. (2015). Critical Insights into an Integrated Literature Review on Customers' Adoption of Islamic Banking Research. International Journal of Scientific Research and Innovative Technology, 2 (6) $45-57$.

Hair, J. F., Anderson, R.E., Tatham, R.L. \& Black, W.C. (1995). Multivariate Data Analysis, 3rd ed, Macmillan Publishing Company, New York.

Hair, J.F., Black, W.C., Babin. B.J., \& Anderson, R.E. (2009). Multivariate Data Analysis, 7th ed. New Jersey : Prentice Hall.

Hanzaee, K.H., Attar, M.M., \& Alikhan, F. (2011). Investigating the Effect of Gender Role Attitude on the Relationship Between Dimensions of Religiosity and New Product Adoption Intention. World Applied Sciences Journal, 13(6) 1527-1536.

Haron, S., Ahmed, N., \& Planisek, S.L. 1994. Bank Patronage Factors of Muslim and non-Muslim Customers, International Journal of Bank Marketing, 12(1) 32-40.

Ismail, S., Azmi, F., \& Thurasamy, R.(2014). Selection Criteria for Islamic Home Financing in Malaysia. International Journal of Business and Society, 15 (1), 97-110.

Jansson, J. (2011). Consumer Eco-Innovation Adoption: Assessing Attitudinal Factors and Perceived Product Characteristics. Business Strategy and the Environment, 20(3) 192-210.

Kaabachi, S., \& Obeid, H. (2014). The Islamic Bank in Tunisia: Brakes, Motivations and Expectations of the banking clientele. Banque et Strategie, 323 41-50.

Khan, A.K., \& Khanna, T. (2010). Faith a luxury for the rich? Examining the influence of religious beliefs on individual financial choices. Retrieved from: http://people.hbs.edu/jsiegel/ KhanKhanna201004.pdf.

Mahmoud, L.O.M., \& Abduh, M. (2014). The Role of Awareness in Islamic Bank Patronizing Behavior of Mauritanian: An Application of TRA. Journal of Islamic Finance, 3(2) 30-38.

Metawa, S.A., \& Almossawi, M. (1998). Banking Behavior of Islamic Bank Customers: Perspectives and Implications. International Journal of Bank Marketing, 16(7) 299-313.

Naser, K., Jamal, A., \& Al-Khatib, K. (1999). Islamic Banking: A Study of Customer Satisfaction and Preference in Jordan. International Journal of Bank Marketing, 17 (3) 135-150.

Nunnally, J.C. (1978). Psychometric Theory, 2nd ed. McGraw-Hill Book Company, New York: 86-113.

Rahim, FA., \& Amin, H. (2011). Determinants of Islamic insurance acceptance: an empirical analysis. International Journal of Business and Society, 12(2), 37-54.

Rammal, H.G., \& Zurbrugg, R. (2007). Awareness of Islamic Banking products among Muslims: The case of Australia. Journal of Financial Services Marketing, 12(1), 65-74.

Rogers, E.M. (1995). Diffusion of Innovations, 4th ed. The Free Press, NY.

Rogers, E.M. (2003). Diffusion of Innovations, 5th ed. The Free Press, NY.

Sekaran, U. (1992). Research Methods for Business - A skill building approach, 2nd ed. United States of America: John Wiley \& Sons, Inc.

Slimene, N., Makni, S. \& Ben Rejeb, J. (2014). Ethical Performance of Islamic Banks: the Case of the Tunisian Banking Zaytuna. Journal of Islamic Banking and Finance, 2(1), 107-122. 
Souiden, N. \& Jabeur, Y. (2015). The impact of Islamic beliefs on consumers' attitudes and purchase intentions of life insurance. International Journal of Bank Marketing, 33(4), 423- 441.

Souiden, N. \&Marzouki, R. (2015). Consumer attitudes and purchase intentions toward Islamic banks: the influence of religiosity. International Journal of Bank Marketing, 33(2), 143-161.

Sun, S., Goh,T., Fam, K.S., \& Xue,Y. (2011). The influence of religion on Islamic mobile phone banking services adoption. Journal of Islamic Marketing, 3 (1) 81-98.

Taylor, S., \& Todd, P. (1995). Decomposition and crossover effects in the theory of planned behavior: A study of consumer adoption intentions. International Journal of Research in Marketing, 12(2) 137-156.

Thambiah, S., Ismail, H., \& Ezu, U. (2011). Customer Awareness and Current Usage of Islamic Retail Banking Products and Services in Malaysia. Australian Journal of Basic and Applied Sciences, 5 (10) 667-671.

Thambiah, S., Ramanathan, S., \& Mazumder, M.N.H. (2012). The Determinants of Islamic Retail Banking Adoption in Malaysia. International Business and Economics Research Journal, 11(4) 1-12.

Thomson Reuters (2013). Tunisia Cautiously Optimistic. Islamic Finance Country Report. Retrieved from: http// www.irti.org/English/Research/.../Report-4.pdf.

Tornatzky, L.G., \& Klein, K.J. (1982). Innovation Characteristics and Innovation Adoption-Implementation: A Meta-Analysis of Findings. IEEE Transactions on Engineering Management, EM-29(1) 28-45.

Venkatesh, V., \& Davis, F.D. (2000). A Theoretical Extension of the Technology Acceptance Model: Four Longitudinal Field Studies. Management Science, 45 (2) 186-204.

Wahyuni, S. (2012). Moslem Community Behavior in the Conduct of Islamic Bank: The Moderation Role of Knowledge and Pricing. Procedia - Social and Behavioral Sciences, 57(9) 290-298.

Wahyuni, S., \& Arifin, T. (2013). Knowledge as an antecedent variable of intention to use Islamic banking product. Retrieved at: http://aasic2013.permitha.net/Proceedings/ICBESS_Proceeding/Volume/icbess-p028.pdf.

Zainuddin, Y., Jahyd, N., \& Ramayah, T. (2004). Perception of Islamic Banking: Does It Differ among Users and Non Users. Journal of Management and Business, 6(2) 135-149.

Zikmund W G. (2003). Business Research Methods, 7th edition, Thomson/South-Western, 748 pp. 